\title{
Performance Analysis and Liquidation Preference under Insolvency and Bankruptcy Code in India
}

\author{
Priyanka Srivastava, Research Scholar, Shri Ramswaroop Memorial University, \\ Uttar Pradesh, India, Email ID: priyankarajrai@gmail.com \\ Manoj Kumar, Associate Professor, Shri Ramswaroop Memorial University, \\ Uttar Pradesh, India Email ID: drmanoj040@gmail.com \\ Rinki Verma, Associate Professor, Shri Ramswaroop Memorial University, \\ Uttar Pradesh India. Email ID: rinki.mnnit@gmail.com
}

\begin{abstract}
The Insolvency and Bankruptcy Code (2016) was introduced with the main objective of maximization of value of assets and revival of stressed assets. The paper analyses the performance of the Insolvency and Bankruptcy Code (IBC) 2016 on various parameters since its inception. The paper emphasises the fact that in order to achieve the timeline whether the code is favouring liquidation over resolution. The paper is qualitative in nature analyzing the performance of the IBC on various parameters. The study finds out that the code has given positive results on the resolution of insolvency of 12 major NPA accounts as compared to other previous schemes but in order to prove its efficacy it has somewhere missed its major objective of resolution of stressed assets, which is its primary objective, and favored liquidation. The paper will give an overview of the performance of the code which is a gap in literature as it is a new code in Indian insolvency regime.
\end{abstract}

Keywords: Insolvency, Bankruptcy, Insolvency and Bankruptcy Code, Liquidation, Resolution, Non - Performing Assets

\subsection{Introduction}

The main aim of a bankruptcy law should be to make available a systematic process through which a financially distressed should first be able to organize itself failing which, it establishes a procedure to liquidate the firm through which the investors get their money back. The aim of any bankruptcy law should be to keep viable business running and avoid premature liquidation. It should aim at the value of the assets should be maximised so that all the stakeholders get their share of dues. The employees and other stakeholders' will be greatly impacted by the liquidation of the firm (Karen, 1994; Ronald, 1995; Karen, 1997). A strong bankruptcy law and strong enforcement will discipline the financial behaviour of the borrower and will force them to make more practical decisions and avoid unnecessary risk (Classens et all, 2003). Studies have shown that an effective bankruptcy regime leads to lower cost of credit due to its increased accessibility, increased recovery for creditors and increased job security (Armour, Menezes, Uttamchandani, \& Zweiten, 2015). Different countries have different models of insolvency resolution. Debtor in possession which is followed in the US and Creditor in Control which is practiced in U.K. are the two main types of insolvency resolution models. It is still under debate that which type is better as it depends upon the lenders, creditors, investors, employees, government and society at large. The two alternative corporate bankruptcy structures are reorganization or liquidation. Bankruptcy laws in most countries have provisions, with varying accessibility for both the structures (Kaiser 
1996). In India, there was no proper bankruptcy law. There were multiple laws which overlapped each other thus making recovery very difficult. The ineffectiveness of the resolution schemes led to a humungous increase in the non-performing assets of the banks and financial institutions. The reforms in Indian insolvency regime was much needed as and was advocated from different quarters which identified India's weak insolvency regime, in practice and in paper, as one of the reasons for malfunctioning of the country's credit market (Bannerjee et al 2012; Sane and Thomas 2012; Rajan 2008). It was due to this that the government introduced the new Insolvency and Bankruptcy Code (IBC) in 2016. The paper analyses the progress of the IBC on various parameters and then discusses the findings of the study. The paper also analyses whether in order to achieve the timeline, whether the code is favouring liquidation over resolution.

\subsection{Insolvency and Bankruptcy Code (IBC) 2016}

At the time when India is set to become an emerging economy, to sustain its growth rate, it was imperative that the earlier insolvency resolution schemes had to be revisited. Any obstacles on the path of moving ahead was to be taken care of. In this context a well-defined insolvency resolution law with well-defined timelines was required. Studies have shown that protection of creditor's right through well-defined legislation supports a robust credit market. Studies have also shown that when creditors can easily enforce repayment they are more willing to extend credit at a lower cost. Studies done by various authors for example Aghion and Bolton (1992), Porta et.all (1996, 1997), Levine and Qian and Strahan (2007) have supported it. The Insolvency and Bankruptcy Code (2016) was one of the much-needed economic reforms which was required by the Indian economy. The new code repeals act like Presidency Towns Insolvency Act, (1909), Provincial Insolvency Act, 1920, and makes amendment in 11 Indian Partnership Act, 1932, The Companies Act, 2013, Securitization and Reconstruction of Financial Assets and Enforcement of Security Interest Act, 2002, Limited Liability Partnership Act, 2008, Sick Industrial Companies (Special Provisions) Repeal Act, 2003. The new code has created the necessary institutions consisting of Insolvency and Bankruptcy Board of India (IBBI) as the regulatory authority, Insolvency Professionals to act as intermediaries for smooth transition to liquidation or takeover, Information Utilities which store information for all firms and an adjucating mechanism to facilitate resolution of the bankrupt corporate within the stipulated time period if necessary also liquidation. The creditors assess the viability and agree mutually for resolution or liquidation.

\subsection{Literature Review}

Corporate Bankruptcy laws in many countries have seen major changes over the past centuries. Despite the changes, there are enormous differences between the Bankruptcy laws of Different countries. Mainly there are two sets of literature of bankruptcy law The legal structure in some countries aims to protect the interest of lenders and suppliers of goods whereas in other countries, the focus is more towards protecting the existing venture, its management and employees. While reorganisation generally favours the debtor, a liquidation favours the creditors. The literature review of this paper is mainly done in the field of bankruptcy laws worldwide and in the Indian Bankruptcy law and its efficiency. Another set of literature is there which deals in the post efficiency of the bankruptcy law i.e. the waterfall of the proceeds recovered.

There are two different set of beliefs regarding bankruptcy law - the traditionalists and the proceduralists. It is believed by the traditionalists that a bankruptcy law of a country is an important factor in the rehabilitation of firms, without which the firms would fail. The proceduralists deny this fact and they believe that firms must live and die in the market 
(Douglas 1998). Optimal bankruptcy law may differ from each other and may depend upon the information structure of the economy. They have differentiated countries according to the economic systems like a well-developed economy like Germany which is bank based and information acquisition is very good and much of the financing is done by the banks, creditor-based bankruptcy law is suitable. In developed countries with market-based financing and technology which assist in acquisition of information are well developed, an optimal bankruptcy law would include both debtor chapter and a creditor chapter. An optimal bankruptcy law for a country with underdeveloped information acquisition technologies and concentrated financing includes both debtor as well as creditor chapter in its optimal bankruptcy law (Elazar Berkovitch and Ronen Israel 1999). Countries where judicial system are strong and also the investor protection laws, it leads to development of financial markets resulting in better and larger credit markets. Investor protection is better in common law countries and civil law countries provide least investor protection (La Porta, Lopez- deSilanes and Vishny 1999). It is the government policies which play an important role in the formation of relationship of debtors and creditors and bankruptcy laws (Schwartz 1998). There is a positive relationship between the bankruptcy law of a country and growth of industrial firm across a wide cross section of countries (King and Levine 1993).

A good insolvency law must be able to differentiate between economically distressed firm and financially distressed firm and it must ensure that economically distressed firm is liquidated while firm which is financially distressed is revived either by reorganizing it among existing stakeholders or by selling it to new investors. It is after this only that an efficient insolvency law will be able to achieve ex post efficient outcome that maximises the total value of proceeds among claimants- in money terms ( $\mathrm{P}$ Aghion, $\mathrm{O}$ Hart and $\mathrm{J}$ Moore 1994). The quality of laws based on legal origins is only a indicator of efficiency of a bankruptcy law while efficient enforcement of the law is major indicator of economic growth (Berkowitz, Pistar and Richard 2000).

A poorly designed bankruptcy law destroys the value of the asset and compels the firm for liquidation. JL Westbrook (2004). There are three stages for the success of an efficient bankruptcy law. The first stage is ex ante stage where the screening mechanism which prevent the borrowers to take imprudent loans while the lenders should be prevented from giving loans that have high probability of default. Second stage is where a bankruptcy law should not deter an entrepreneur from taking risk and the third stage is where an insolvency law should be able to deliver efficient outcome i.e. maximisation of value of assets Classens and Klapper (2005). When we compare the insolvency laws Kevin M.J. Kaiser (1996) summarises and compares the bankruptcy law of US, UK, France and Germany with emphasis on the legal system in reducing the difficulties of distressed debtor. Julian R. Franks, Kjell G. Nyborg, and Walter N. Torous (1996) have compared the efficiency of the insolvency codes of US, UK and Germany. They have judged the efficiency on three stages of bankruptcy process - ex ante, interim and ex post. The authors have analysed the insolvency codes of these countries as well as compared them also on certain benchmarks. The authors have concluded by stating the significance of all the three codes.

While coming on Indian bankruptcy law the evolution of corporate insolvency resolution schemes of India due to their piecemeal approach of the schemes and solving only one problem at a time, resulted in inefficient results on the overall objective. IBC as modern law which will be able to solve all insolvency resolution problem under current Indian scenario (Rajeswari Sengupta, Anjali Sharma, Susan Thomas 2016). Aparna Ravi 2015 has attempted to analyse the implementation of insolvency regime in practice in India prior to IBC. The author has brought the processes which are involved when a bankrupt firm enters the legal 
process of Insolvency. The pre insolvency issue of 'initiation problem' is an implementation problem of the IBC. The directors of the company are reluctant in initiating the IBC process and are unwilling to let go the control of the company. He proposes a 'Revlon Duty Model' while seeking bids which will incentivize the directors to act in reviving the company rather than retaining control to the point of liquidation (Kamalnath( 017)

The international studies which deal in insolvency and bankruptcy laws have majorly concentrated themselves towards an optimal bankruptcy law or a comparison of insolvency laws of different nations. They have either discussed the two models of bankruptcy law i.e. debtor in possession and creditor in control model or a mix of both. If we talk about Indian context, there is a shortage of literature on bankruptcy laws and those which exist they are mainly in criticism of the previous insolvency laws. After the introduction of the IBC, the literature on this topic mainly focusses on legal aspect of the code. Some literature is there on the representation of the stakeholders as well as on the regulatory framework of the code. This may be due to the newness of the code as no other area was explored. As can be seen from the above reviewed literature that bankruptcy laws are different in each country depending upon the structure of the economy and information system. It was also seen that the aim of a good bankruptcy law should be reorganisation of financial distressed firms so that they can be revived and if it is not possible to revive then liquidation should be opted. Liquidation should not be the main aim for insolvency resolution. Few literatures are there about the new Insolvency and Bankruptcy Code (2016) and its performance.

\section{Objectives of the Study}

Based on the literature review done, there is a gap about the progress of the IBC on various parameters so far and there is also gap in literature about the analysis of liquidation cases i.e. whether the new code is favouring liquidation over resolution Based on the law, the gaps identified for this particular study was undertaken with the following objectives in mind:

1. To analyze the progress of Insolvency and Bankruptcy Code in insolvency resolution.

2. To analyze whether the Insolvency and Bankruptcy Code is favoring liquidation over resolution.

\subsection{Statistics of the IBC Code}

The data has been collected from various sources like RBI publications, IBBI website among others. The data was collected in order to present the progress of IBC so far as well as present the fact so far liquidation cases were more than the resolution cases which is not the main aim of the new code. The performance of the code has been judged on various parameters like status of cases, resolution timeline, resolution and liquidation and the status of twelve large NPA accounts. 


\subsection{Status of Cases}

Table 1: Quarter wise cases under IBC

\begin{tabular}{|c|c|c|c|c|c|c|c|}
\hline Quarter & $\begin{array}{l}\text { CIRP at the } \\
\text { beginning }\end{array}$ & $\begin{array}{l}\text { Admitte } \\
\text { d }\end{array}$ & $\begin{array}{l}\text { Appeal } \\
\text { or } \\
\text { Reviewe } \\
\text { d or } \\
\text { settled }\end{array}$ & $\begin{array}{l}\text { Withdrawa } \\
\text { I under } \\
\text { section } 12 \\
\text { A }\end{array}$ & $\begin{array}{l}\text { Resolutio } \\
\text { n plan } \\
\text { approved }\end{array}$ & $\begin{array}{l}\text { Liquidation } \\
\text { plan } \\
\text { commence } \\
\text { d }\end{array}$ & $\begin{array}{l}\text { CIRP } \\
\text { at } \\
\text { end }\end{array}$ \\
\hline $2016-17$ & 0 & 37 & 1 & 0 & 0 & 0 & 36 \\
\hline $2017-18$ & 36 & 706 & 94 & 0 & 20 & 91 & 537 \\
\hline $2018-19$ & 537 & 1156 & 149 & 97 & 79 & 305 & 1063 \\
\hline $\begin{array}{l}\text { April-June } \\
2019\end{array}$ & 1063 & 301 & 53 & 32 & 26 & 96 & 1157 \\
\hline $\begin{array}{l}\text { July- Sept. } \\
2019\end{array}$ & 1157 & 596 & 57 & 51 & 34 & 156 & 1455 \\
\hline $\begin{array}{l}\text { Oct. - Dec. } \\
2019\end{array}$ & 1455 & 637 & 114 & 60 & 42 & 153 & 1723 \\
\hline $\begin{array}{c}\text { Jan. - March } \\
2020\end{array}$ & 1723 & 444 & 95 & 58 & 39 & 137 & 1838 \\
\hline $\begin{array}{l}\text { April-June } \\
2020\end{array}$ & 1838 & 84 & 13 & 27 & 20 & 26 & 1836 \\
\hline $\begin{array}{c}\text { July - Sept. } \\
2020\end{array}$ & 1836 & 96 & 25 & 35 & 35 & 81 & 1756 \\
\hline $\begin{array}{l}\text { October - } \\
\text { Dec. } 2020\end{array}$ & 1756 & 107 & 8 & 30 & 24 & 83 & 1718 \\
\hline $\begin{array}{c}\text { Jan. - March } \\
2021\end{array}$ & 1718 & 212 & 8 & 21 & 29 & 149 & 1723 \\
\hline Total & & 4376 & 617 & 411 & 348 & 1277 & $\begin{array}{c}172 \\
3\end{array}$ \\
\hline
\end{tabular}

Source: IBBI

The table above shows the progress of IBC every quarter since it came into force till March 2021. The total number of cases which have been admitted till March'21 was 4376. The total number of cases which were appealed/review were 617 while the cases which were withdrew were 411 cases. The total number of resolute cases were only 348 which was much less than the liquidated cases which are 1277. 


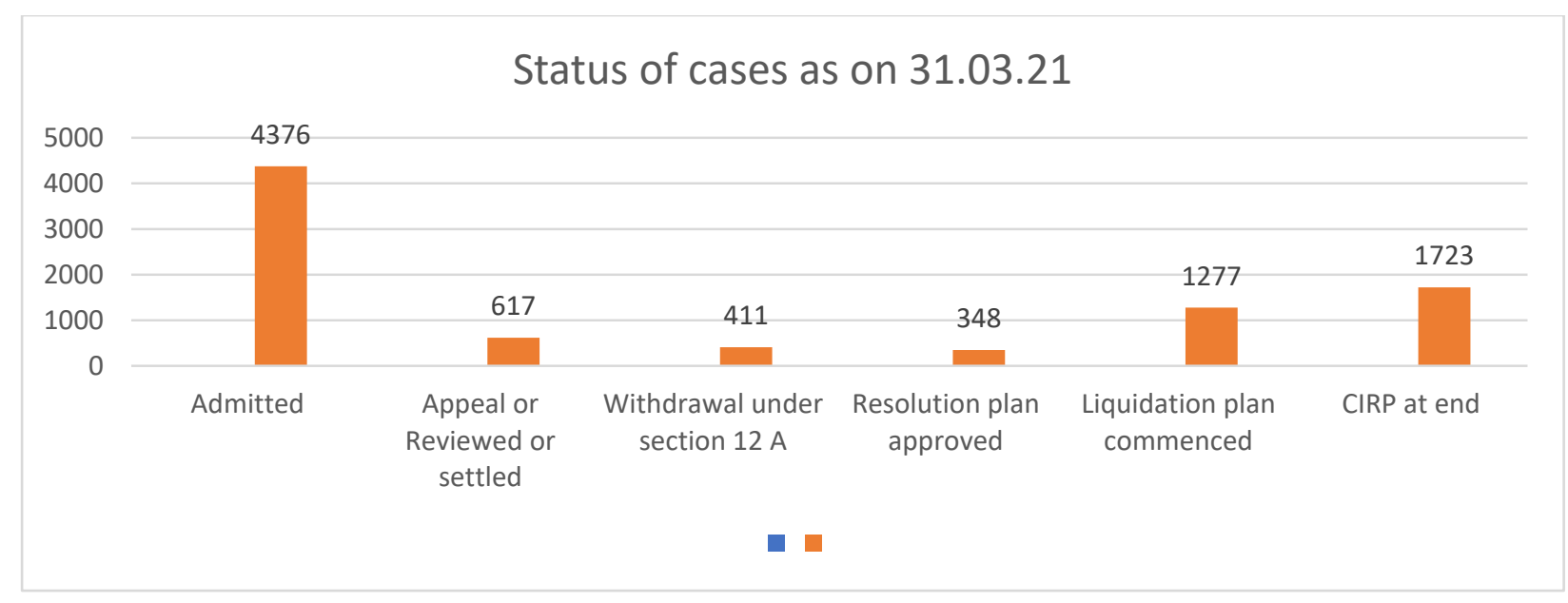

Source: IBBI

Fig. 1: Number of cases as per their status on 31.03.2021

\subsection{Resolution Time}

If we analyse it can be seen that only $12 \%$ of the cases i.e. 210 cases till March 21 were resolved within less than or equal to 90 days, $5 \%$ (88) cases took more than 90 days and less than or equal to 180 days, $4 \%$ (67) cases were resolved between 181 days and 270 days while $79 \%$ (1358) cases took more than 270 cases to be resolved.

\section{Out of 1723 CIRP going on}

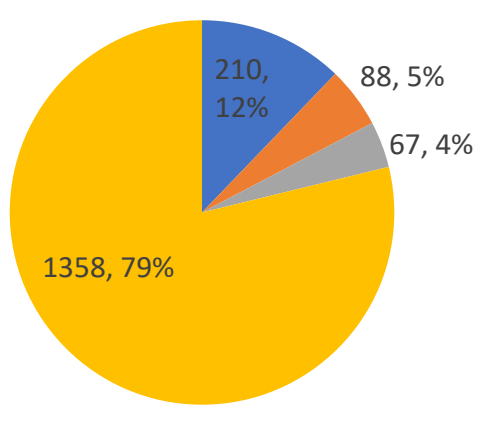

$\square<90$ days

- $>90$ days $<180$ days

$\square<180$ days $>270$ days

$>270$ days

Fig. 2 : Status of CIRP cases on the basis of resolution time

Source : IBBI

\subsection{CIRP initiation}

It can be seen from fig (iii) that out of the total CIRP cases initiated, 2225 cases were initiated by the operational creditors (OC) while 1875 cases were initiated by financial creditors (FC) and 276 cases were initiated by corporate debtors (CD). 


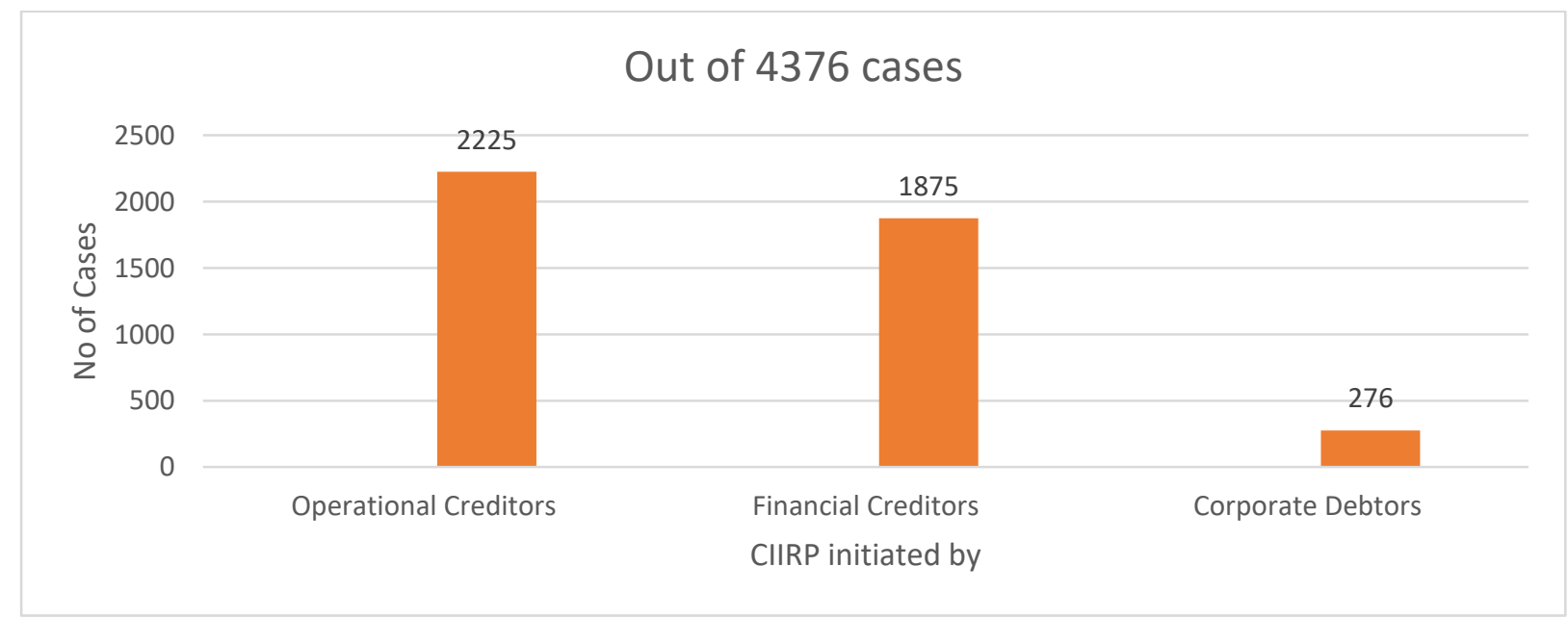

Fig. 3: Initiation of CIRP by various stakeholders

Source : IBBI

\subsection{Resolution and Liquidation}

Out of total 1523 cases, which were closed, only of 348cases resolution plan was passed as compared to liquidation cases which was 1277 cases, a figure much higher than the resolved cases.

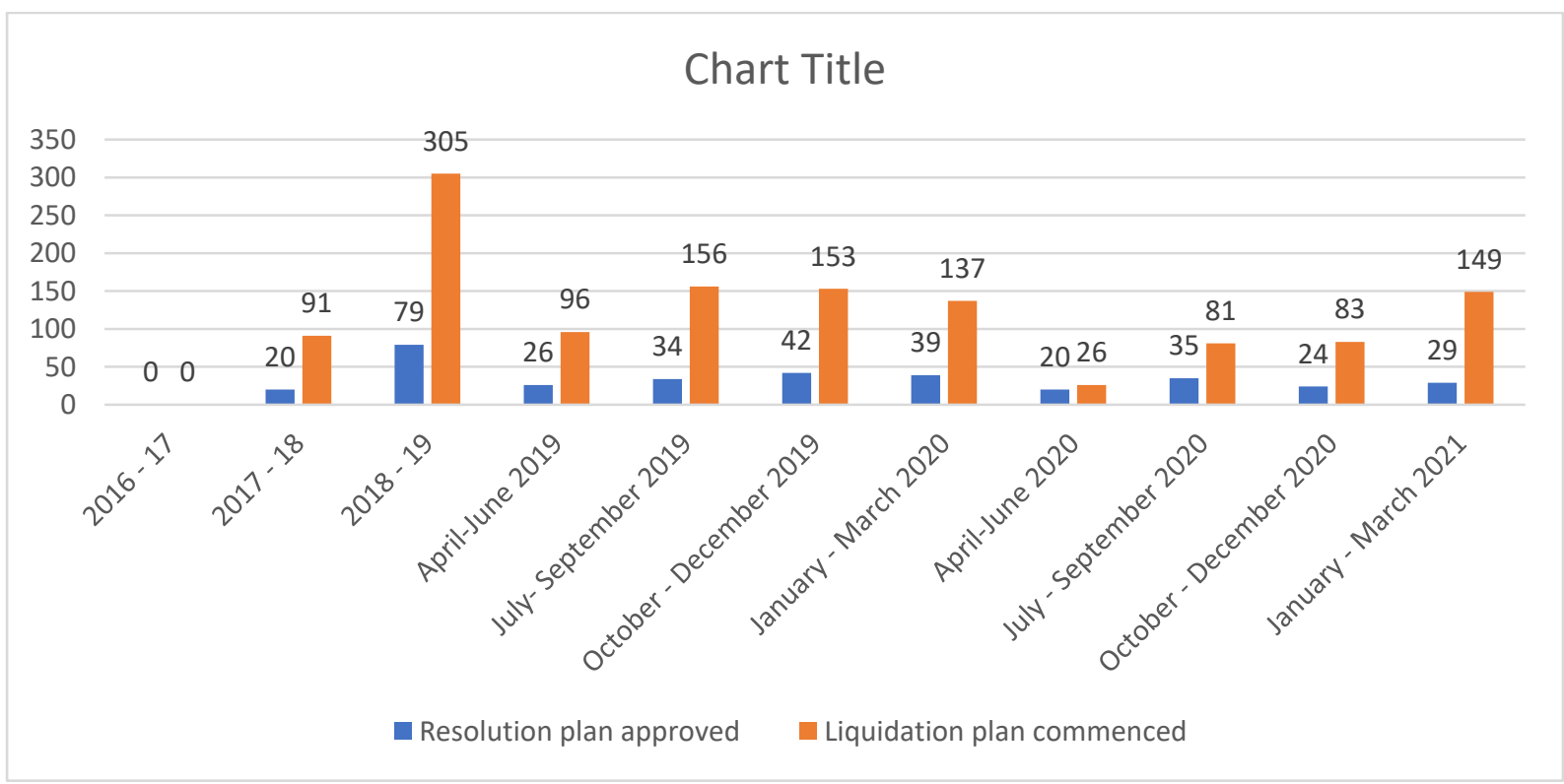

Fig. 4: Resolution Vs Liquidation cases

Source: IBBI 


\subsection{Twelve large NPA accounts}

One of the major parameters where the performance of the new code can be judged is the status of 12 large NPA accounts which were sent to IBBI for resolution by RBI. Together these accounts amounted to Rs 3.45 lakh crores against the liquidation value of Rs 73,220 crores.

Table 2 : Status of 12 large NPA accounts as on 31.03.2021

\begin{tabular}{|c|c|c|c|c|c|}
\hline Name of Corporate Debtor & \begin{tabular}{|l|} 
Amount \\
Admitted in ( Rs \\
billion)
\end{tabular} & \begin{tabular}{|l|} 
Amount \\
Realizedin Rs \\
billion)
\end{tabular} & $\begin{array}{l}\text { \% realized of } \\
\text { claims }\end{array}$ & \begin{tabular}{|l|} 
claim \% of \\
liquidation \\
amount \\
\end{tabular} & Successful bidder \\
\hline & & \multicolumn{2}{|l|}{ CIRP completed } & & \\
\hline Electrosteel Steel Itd & 131.75 & 53.2 & 40.38 & 183.45 & vedanta Itd \\
\hline Bhushan Steels & 560.22 & 355.71 & 63.5 & 252.88 & Banipal Steel \\
\hline Monnet Ispat \& Energy Pvt Ltd & 110.15 & 28.92 & 26.26 & 123.35 & JSW \& AION \\
\hline Essar Steel India Itd & 494.73 & 410.18 & 82.91 & 266.65 & Arcellor Mittal \\
\hline Alok Industries & 295.23 & 50.52 & 17.11 & 115.39 & Relaince Industries \\
\hline Jyoti Structures & 73.65 & 36.91 & 50.12 & 387.44 & Group of HNI led by Sanjay San: \\
\hline Bhushan Power \& Steel & 471.58 & 193.5 & 41.03 & 209.12 & JSW Itd \\
\hline Jaypee Infratech & 231.76 & 232.23 & 100.23 & 130.82 & NBCC (ndia) Itd \\
\hline \multirow[t]{2}{*}{ Amtek Auto } & 126.41 & 26.15 & 20.68 & 169.65 & Deccan Value Investors \\
\hline & & \multicolumn{2}{|c|}{ CIRP under process } & & \\
\hline Era Infra Engineering Itd & Under resolution & & & & \\
\hline Lanco Infratech Itd & Under liquidation & & & & \\
\hline ABG Shipyard & Under liquidatior & & & & \\
\hline
\end{tabular}

Source : IBBI

\subsection{Findings and Discussion}

The aim of this study is to analyse the progress of Insolvency \& Bankruptcy Code (IBC) and also to analyse whether the code is preferring liquidation over resolution. This study will add a new literature to the existing study which mainly focusses on legal aspects or on the regulatory framework of the new code. We can see that out of the total 4376 case admitted for resolution under the code only 2653 have been closed. It can be further analysed from fig (i) that out of 2653 closed cases $48.13 \%$ cases were liquidated as compared to $13.11 \%$ cases ended up with a resolution plan. $15.4 \%$ of the cases were withdrawn for different reasons under section $12 \mathrm{~A}$ of the code while $23.25 \%$ cases were under review or appeal. 1723 cases are still undergoing CIRP. Majority of the cases were liquidated (see table (i)).

One of the major characteristics of the new code which makes it superior to other previous insolvency schemes is its time factor which the earlier scheme defaulted upon which led to enormous increase in stressed assets. The time period allotted for resolution of insolvency was 180 days +90 days addition i.e. a total of 270 days was given. The World Bank Report 2016 in its has recognised the time factor as a very important aspect in country ranking. It has also recognised cost, outcome and effectiveness of judicial system as other factors in determining the ranking of the countries. (World Bank (2016), Doing Business 2016) If we analyse the data (see fig (ii)) it can be seen that around $79 \%$ of the cases have breached the timeline of resolution due to procedural inefficiencies and lack of proper infrastructure and other frivolous matter and have exceeded the upper limit of 270 days and only $17 \%$ of the cases were able to be resolved within 180 days. If we analyse the initiation of the cases, we can see that out of 4376 admitted cases 2225 cases were initiated by the operational creditors (OC) whereas 1875 cases were initiated by financial creditors (FC) while 276 cases were 
initiated by corporate debtors (CD) themselves. The progress of the code could also be ascertained on the resolution of the 12 large NPA accounts which were sent for CIRP at the behest of RBI. These constituted about Rs 345000 crore whereas Rs 73220 crores was the liquidation value. Approval of resolution plan in case of 8 corporate debtors have been initiated and 2 corporate debtors have been ordered for liquidation. One CD CIRP has stared while one the CIRP is going on. The table also shows the percentage of amount realised in respect to claims put up by the FCs. Out of eight cases the case of Jaypee Infratech had realised $100.23 \%$ of its claim which is very good. In case of Essar Steel India Ltd. also the creditors have realised $82.91 \%$ of their claims and in case of Bhushan Steel also they have realised $63.50 \%$ of their claims. But in some cases, the recovery is very low and the banks had to take steep haircuts as in case of Alok Industries ltd where realisation was only $17.11 \%$ and in Monnet Ispat \& Energy Ltd it was $26.26 \%$. But if we analyse the performance of the IBC on the basis of 8 cases, we can say that the realised amount of Rs 136117 crore against Rs 73,220 crore liquidation value of 12 cases is quite encouraging.

If we analyse the cases resolved vs the cases liquidated, we can see that the bill has a marked preference for liquidation as out of 1523 cases closed only 348 cases have a resolution plan while in 1277 cases liquidation order has been passed. As per the concerned authority the increase in the number of liquidation cases is because most of the cases which are liquidated were already sent to BIFR for resolution or were non- operational. There was already erosion of the economic value before they were admitted for resolution. These CDs had less than 5\% of the outstanding debt amount. (IBBI). The Committee of Creditors consists of the FC which may incline towards liquidation rather than resolution in order to recover their dues. Another reason which could be assigned for more liquidation could be that the resolution period of 180 days is very less. The period of 180 days is a very ambitious time as to decide upon a viable resolution plan which is agreed upon all the creditors (Ashish Pandey 2016). The period of 180 days is very less to consider all the factors like the size of the firm, financial performance etc and without judging these factors it would lead to liquidation proceedings eroding its intrinsic economic value.

\subsection{Conclusion}

In the words of President Ram Nath Kovind in a joint session of parliament held on June 20, 2019 "Insolvency and Bankruptcy Code is among the biggest and most impactful economic reforms undertaken in the country. With the coming into force of this Code, banks and other financial institutions have been able to settle directly or indirectly an amount of more than 3 lakh 50 thousand crore. This Code has also curbed the tendency of wilfully defaulting on loans taken from the banks and other financial institutions".

The code is indeed an upliftment of the bankruptcy law in India and it will bring us to an international level in resolving insolvency and promote entrepreneurship. The foreign investors are definitely going to analyse the Corporate Insolvency Resolution Process (CIRP) of IBC. So, it is very necessary that the shortcoming s which have been encountered should be removed so that the efficient working is not hampered. It is required that the regulatory and judiciary body should make it more efficient according to the needs of the corporate world. Time is the major essence of this code. If the timeline is not adhered to, it may happen that the code may meet fate like previous schemes. The authorities should look into this matter and frame a practical timeline depending upon the size of the firm, financial status prior to initiating bankruptcy etc. Liquidation cases are more than the resolved cases which may be hasty decision due to lack of time in properly drafting a resolution plan. The CoC 
should look into all the resolution plans before going for liquidation. The main aim of a good insolvency scheme should be resolution and not liquidation. The insolvency law should be more concentrated on reorganisation and restructuring (Donald, 1991; Elizabeth 1993)

The law is still in its evolving phase and is evolving itself according to the current situation and as per the cases which are coming. Timeline has been increased from initial 180 days to 330 days. Home buyers are included in the list of financial creditors (FC). Financial Service Providers (FSP) which were not included for the process are now included as DHFL has defaulted. The code has performed on the 12 lager NPA cases as eight out of 12 cases have resolution plans and total recovery is more than satisfactory in few cases which otherwise would have been liquidated. After 2016, the code has been swift in making changes and serious efforts have been made to collect and report data on operation of the code and this has provided a basis for thoughtful evaluation of the code. Every effort is being made to preserve the value of debtor's asset to the benefit of creditors.

\section{References}

Aghion, Phillippe, Oliver Hart, and John Moore (1994). Improving bankruptcy procedure. In: Washington Law University Quarterly 72.3, pp. 849-872.

Armour, J., Menezes, A., Uttamchandani, M., \& Zweiten, K. V. (2015). How Creditor Rights Affect Debt Finance. In F. Dahan (Ed.), Research Handbook on Secured Financing in Commercial Transactions. Elgar Publishing.

Claessens, S., Djankov, S., \& Klapper, L. (2003). Resolution of corporate distress in East Asia. World Bank Group, Journal of Empirical Finance, 10, 199- 216.

Claessens, Stijn, \& Klapper, L. (2003). Bankruptcy around the World: Explanations of Its Relative Use. Policy Research Working Paper 2865, World Bank. Washington, DC.

Djankov, S. (2009). Bankruptcy Regimes during Financial Distress. Washington, DC: World Bank.

Donald R. Korobkin, (1991). Rehabilitating Values: A Jurisprudence of Bankruptcy. 91

Colum. L. Rev. 717.

Elizabeth Warren, (1993). Bankruptcy Policymaking in an Imperfect World. 92 Mich. L. Rev. pp.336, 367.

Douglas G. Baird, (1998). Bankruptcy’s Uncontested Axioms. 108 Yale L. J. 573, 578 pp. 577.

Franks, J., Nyborg, K., Torous, w., (1996). A

Kang, N., Nayar, N. (2004), The Evolution of Corporate Bankruptcy Law in India, Money and Finance, 37- 44

Karen Gross, (1994). Taking Community Interests into Account in Bankruptcy An Essay. 72 Wash. Univ. L. Q. 1031; 
King and Levine (1993). Finance and Growth : Schumpeter might be Right, The Quarterly Journal of Economics, Vol 108, Issue 3,717-737

Pandey A., (2016), The Indian Insolvency and Bankruptcy Bill: Sixty Years in the making, Vol 8 Issue 1

Ravi, Aparna (2015).The Indian Insolvency Regime in Practice: An Analysis of Insolvency and Debt Recovery Proceedings. In Economic and Political Weekly.

Rasmussen, K. Robert, (1994).An Essay on Optimal Bankruptcy Rules and Social Justice. U. Ill. L. Rev. 1, 43.

Ronald J. Mann, (1995). Bankruptcy and the Entitlements of the Government: Whose Money is it Anyway 70 (5) N.Y.U L. Rev. 1040;

Schwartz A., (1998). A Contract Theory Approach to Business Bankruptcy. 107 Yale L. J.1807, 1851 .

Zwieten, Kristin Van (2015). “Corporate Rescue in India: The Influence of the Courts”. In: Journal of Corporate Law Studies 1.

World Bank (2016), Doing Business 2016: Measuring Regulatory Quality and Efficiency, 13th edition, A World Bank Group Flagship Full Report, Washington. Retrieved from : http://www.worldbank.org

Book Karen Gross, Failure and Forgiveness: Rebalancing the Bankruptcy System (New Haven: Yale University Press, 1997) 253

\section{$\underline{\text { Standard Database }}$}

Reserve Bank OfIndia, publications, www.rbi.org.in/scripts/publications

Report on Trend and Progress of Banking, https://rbidocs.rbi.org.in/rdocs/publications

Insolvency and Bankruptcy Board of India, www.ibbi.gov.in/publications

Doing Business Report, www.doingbusiness.org 